\title{
WOMEN AS MANAGERS IN THE HEALTH SERVICES
}

\author{
Jocelyne Kane-Berman
}

\section{Uittreksel}

Oor die algemeen beklee vroue ten spyte van hul getalle-oormaat nie posisies van mag en gesag in gesondheidsdienste nie. Dit word aanvaar dat dit as gevolg van 'n verskeidenheid faktore is dat vroue verhoed word om hulle volle potensiaal as bestuurders te bereik. In ander dele van die wêreld sowel as in Suid-Afrika het middelklas blanke mans gesondheidsdienste oorheers sedert geneeskunde in formele wetenskap geword het en daarmee die tradisionele rol van vrouens as genesers toegedien. Sommige navorsing dui daarop dat vrouens geneig is tol die praktisering van "vroulike" hestuurst vle. Daar word voorgestel dat die vroulike/manlike onderskeid kunsmatig is en dat eienskappe wat goeie bestuur verseker nie as geslagsgekoppeld beskou moet word nie. Leiers in gesondheidsdienste moer streef na interdissiplinêre opvoeding en opleiding wat nie op geslagskeiding berus nie. Bepaling en ontwikkeling van bestuurspotensiaal. rolnabootsing en beskermheerraadgewer verhoudings moet aangemoedig word sodat vroue hul volle spektrum van bestuursvaardigheid kan verkry. Sodoende kan hulle posisies van mag en gesag in gesondheidsdienste bereik.

\section{Abstract}

Despite their numerical superiority women do not occupy positions of power and authority in the health services generally. This is perceived as being due to a variety of factors which prevent women from realising their full potential as managers. In other parts of the world, as well as in South Africa. middle class white males have dominated health services, since medicine became a formal science, usurping the traditional role of women healers. Some research indicates that women are inclined to practice "feminine" management styles. It is suggested that the feminine/masculine dichotomy is artificial and that qualities which ensure effective management should not be regarded as genderlinked. Leaders in the health services should strive for interdisciplinary. mixed-gender education and training at all levels. Identification and development of management potential in women health-care professionals, role-modelling and sponsor-mentor relationships should be encouraged to allow women to acquire the full range of management skills and to achieve positions of power and authority in the health services.
Women predominate numerically in the health care occupations, excepting medicine, but have not achieved proportional dominance in positions of power and authority in the health services. This is anomalous in view of the many highly qualified and capable women who have been and are currently active in the teaching and practice of medicine, nursing and the supplementary health-care of essions. The reasons for women's failure to achieve significant status in significant numbers in the political, academic and administrative health arenas are not difficult to identify and pertain to three major factors

- masculine chauvinism

- feminine connivance

- biological and societal constraints

\section{CHAUVINISM}

The traditional and prevailing attitude of men towards women was typified by Freud who frequently admitted his perplexity regarding "The riddle of the nature of femininity" but who, nonetheless, wrote in 1933, "The fact that women must be regarded as having little sense of justice is no doubt related to the predominance of envy in their mental life ... We also regard women as weaker in their social interests and as having less capacity for sustaining their interests than men ... but we do not overlook the fact that an individual woman may be a human being in other respects as well."
In similar vein -- the Earl of

Chesterfield writing to his son in 1848 advised the young man that "Women then, are only children of a larger growth. They have an entertaining tattle, and sometimes wit, but for solid reasoning, good sense, I never knew in my life one that had it, or who reasoned or acted consequently for four and twenty hours together ... or their supposed understanding depreciated, instantly kindles their little passions and overturns any system of consequential conduct. A man of sense ... neither consults them about nor trusts them with serious matters ... for they love mightily to be dabbling in business (which, by the way, they always spoil); ... they almost adore that man who talks more seriously to them, and who seems to consult and trust them. I say, who seems, for weak men rarely do, but wise ones only seem to do it." "2

Such condescending paternalism has diminished, as a consequence of the determined onslaught of feminists, but male chauvinism is not the only obstacle to female advancement.

\section{CONNIVANCE}

Women's collusion in their own oppression is a continuing obstacle to women's progress. Passivity and lack of assertiveness which characterises women's attitudes in the workplace and their acceptance of inadequate pay and lesser status occupations perpetuates society's perception of women as subject beings Freud's analysis of feminine masochism, may explain women's continuing subordination - for those who believe women are incapable of achieving status or exercising power. ${ }^{3}$ Innumerable successful women have, however, disproved this Freudian misconception and serve as role models, sponsors and mentors for those women who reject the victim's role.

Sex segregation, however, encouraged for years by women themselves - in schools, female dominated professions and in a variety of residential establishments in order to keep young girls pure and to protect them from the depredations of men - is a form of societal control of women, perpetuated by women, which has deprived them for decades of the benefits of crossgender experiential learning and role modelling.

This segregation is a form of "homosocial reproduction" as described by Kanter. ${ }^{4}$ Where women hold dominant positions in an organisation or profession they perpetuate themselves and their values and exclude people who differ from this norm. In the health-care professions the cycle of student-teacher-student is restricted to unidisciplinary, single gender structures where cross pollination with, and enrichment by, other disciplines is avoided. This educational model is so universally applied that, regardless of the reasons for its initial development, it is seemingly deliberately maintained by women themselves. In this learning 
situation the female pupil is always in a subservient, master-student relationship with the occasional male teacher, or in a superior-subordinate, senior-junior relationship with males in the work situation. The student usually witnesses her female teachers and superiors enacting subordinate, placatory and supportive roles to the dominant male. The cycle of subordination is thus constantly reinculcated in all female predominant health-care institutions and health-care professions. This iterative, cyclical pattern requires interventional strategies which will integrate the sexes in primary, secondary and tertiary educational programmes and provide for multi-, interdisciplinary sharing of all theoretical and practical professional training.

\section{BIOCULTURE}

This pattern of female subservience has changed - is changing - but women's physiological functions - and societal attitudes - remain as barriers to progress. The introduction of oral contraceptives which enabled women to escape some of the dysfunctions of their sexuality including menstruation and pregnancy has hastened the process but acculturation in patriarchal societies, which pressurise girls into harem roles of serving and pleasing males, is not conducive to maximising female potential. ${ }^{5}$

In terms of sexuality, it can be postulated that women who achieved status in the past were usually those who avoided the societal controls or the physiological consequences of femininity by means of

1. Seclusion - usually for religious reasons.

2. Spinsterhood - voluntary or involuntary.

3. Sterility - pathological or menopausal. Married women in their child-bearing years, before the introduction of oral contraceptives and general improvement in life expectancy, were subjected to ideological and societal controls which made it virtually impossible for them to escape the demands of domesticity and maternity. They were either menstruating, pregnant or breast feeding and usually died before reaching menopause. It was only those few who evaded the iterative cycles of pregnancy and childbirth who had time and energy for creativity or achievement in other areas.

Societal norms differ in different cultures and significantly affect women's perceptions of themselves in relation to society. Moodley, for example, has stated that Hindu women are found in many executive positions in the professions, commerce, industry and government. They do not appear to suffer role-conflict, are wholly feminine but are also assertive, dynamic and powerful. They are considered to be subordinate to their husbands but society regards them as being of equal importance to men and their responsibilities as wives and mothers are accorded high status. Moodley calls this complementary (personal communication). Acculturation is a most potent force in shaping our destinies - as powerful as the biological forces which determine our masculinity or femininity.

\section{WOMEN IN HEALTH CARE}

Women have, for centuries, played a significant role in health care. Hygieia in Greek mythology was the goddess of health, her sister Panacea was the goddess of healing and both were daughters of Aesculapius whose serpent-entwined staff is the emblem of medicine. The healing powers of Europe's wisewomen who had developed an extensive pharmacopoeia of pain killers, digestive herbs and antiinflammatory drugs were often superior to those of the physicians of the day. In their communities they were entrusted with obstetrical care and many were shrewd psycho-therapists. ${ }^{6}$ The traditional healers in other civilisations - including Africa are often women and in many countries women who withdrew to religious communities such as convents were also responsible for providing health care in hospices and infirmaries.

In the Western world, however, the rudimentary medical profession, from the 16th century onwards, established monopolistic practices along class and sex lines. As a body of scientific knowledge developed which could only be taught at licensed medical schools, women were increasingly excluded from formal health care. Not only were they refused entry to the universities but they were also considered unsuitable for the profession of medicine and aroused great antipathy during the late 19th century by their demands for admission to the medical schools. ${ }^{7}$ Those who opposed the idea of female doctors raised no objection, however, to allowing nurses access to patients! Nurses were non-threatening subordinates - regarded as servants and did not challenge masculine authority. The perception of the woman's role in health care is well expressed by a medical administrator who wrote in 1874 "Nursing is the medical work of women... it furnishes an outlet for the tender power and skill of good women of almost every class". 8

The resistance to women as doctors was so powerful that by 1870 there were still only two registered women doctors on both sides of the Atlantic (excluding James Barry whose gender is uncertain) Elizabeth Blackwell in the U.S.A. and Elizabeth Garrett in Britain.

Even women, including Queen Victoria, were strongly opposed to women as doctors - a prejudice which persisted well into the second half of the 20th century. The traditional wisdom of women as lay healers and midwives was also increasingly opposed by the male-dominated medical profession. Female healers operated within a community of shared information and mutual support which had to be destroyed in order to assure the supremacy of the elitist medical profession. Despite the savage persecution of European wisewomen and midwives as witches, midwifery remained the prerogative of women healers until the last decades of the 19 th century - because men considered it beneath them in accordance with the prevailing view of the lowly status of women. Eventually even this feminine preserve was incorporated in the formal structures of male medical care and education - in industrialised countries.

In this century, as other health-care professions developed, the medical profession further extended its control to the training and licensing of these predominantly female occupations specifically nursing, physiotherapy, occupational therapy and radiography.

This very brief outline of women's role in health care in Western capitalist societies indicates that it was almost axiomatic that the higher the status of an occupation the more exclusively it was reserved for middle or upper class males whereas women were relegated to a subordinate status in inferior occupations. 9

\section{THE SOUTH AFRICAN SITUATION} Cilliers has recently researched the situation of women in health service occupations (excluding medicine) in South Africa, based on surveys of nurses, occupational and physiotherapists, dietitians, radiographers and social workers and has identified several important factors

- $69 \%$ of posts in the health services are filled by women.

- The service professions attract more women than men because women prefer the nurturant role. The predominance of women in these professions determines the lesser financial rewards received which in turn discourages men from entering these professions.

- The medical profession in particular and society in general does not accord high status to the practitioners in these occupations.

- Apart from nursing and social work the majority of workers in the supplementary health care professions are married and aged 22-29.

- Apart from nursing - relatively few have post-basic qualification.

- There is a high attrition rate after qualifying. The numbers trained may well need to be doubled to meet the needs - unless ways can be found to encourage young graduates to stay in the service.

- The majority do not regard administrative work as rewarding

- The qualities required for practitioners in nursing and the supplementary health-care professions are - good human relationships

- good communication abilities

- high motivation and discipline

- good technical abilities

- flexibility/adaptability

- organisational and planning skills

- ability to remain calm in a crisis

Cilliers concludes that women are attracted to the service professions by socialisation and the caring and nurturant values instilled in the family and at school. 
The growing demand worldwide for health care will draw increasing numbers of women into the health care professions where they are numerically dominant. ${ }^{10}$ In these circumstances the development of women's management potential becomes a priority objective.

\section{WOMEN AS MANAGERS}

Women as managers - have been, until the second and third decades of this century, restricted to organisations which were either primarily domestic or predominantly female - nursing, teaching, religious communities -- and the Madam. The latter, and the abbesses who were responsible for convents and hospices from early in the Christian era, appear to have been the first women executives - apart from a handful of matriarchs and sovereigns Sheba, Cleopatra, Boadicea and the Tudor and Hanoverian queens of England. Despite the changes which have taken place it appears that women are still generally subordinate to men and are

ainly employed in the low status, poorly munerated occupations. In the United States in the early ' 80 's men still significantly outnumbered women in managerial positions and in the higher status, better paid occupations."I

Slabbert, reporting on research into South African requirements for selecting and training managers, emphasised the management functions of planning, setting objectives, allocating and controlling resources, evaluating achievements and working with and through other people. She identified the critical shortage of managers in the South African workforce $-2 \%$ as opposed to $12 \%$ in industrialised countries - and emphasised the need for prospective managers to be selected and trained from categories other than white males.

Slabbert's research was based on the views of MBA graduates on South African management training and the qualities

quired for managers.

The qualities were classified into technical, interpersonal and administrative and defined the proportions of each required at various levels of management.

In relating her findings to women, Slabbert reached the following conclusions

- Women must understand that they must possess above average abilities in all 3 categories if they are to succeed as managers.

- Self development and training are essential.

- Women who are successful managers must recognise and act on their important function as role models and mentors for younger women. The masculine model of the successful manager can thus be replaced by a feminine or preferably non sex-linked model.

- Women need to develop their own management styles as individuals. 12 Bendeman studied management styles and sex-role stereotyping in the context of certain dominant societal norms.
1. Women are constrained by the feminine attributes of emotionality, passivity, people-orientation and willingness to compromise whereas -.

2. Men are rational, dynamic, aggressive, authoritarian and task orientated.

Bendeman's research amongst workers in the retail sector and municipalities was based on the Blake and Mouton concept of the management matrix and the 3 dimensional management approach of Reddin, which allows for a range of management styles depending on the environment in which the manager functions and the abilities of individual subordinates.

Her findings confirmed that women in supervisory positions, in general, utilised people-orientated rather than taskorientated management styles. This led to problems in the work situation because the women in the sample perceived their contribution as being undervalued, their opinions not considered, promotion opportunities as inadequate and their monetary rewards as insufficient. The solutions lay in changing perceptions of employers, training women to be effective managers and in women developing themselves, their self-confidence, and becoming more assertive. ${ }^{13}$

These authors have not addressed the issue of power and women's inability, in general, to exercise power directly, rather than from behind the throne. "Women are ambivalent about the direct exercise of power and tend to use it deviously". 14 In medicine women have failed to achieve positions of power for a variety of reasons which have been clearly analysed by both Unterhalter and Ames. The failure of other predominantly female health-care professions to achieve significant influence is a consequence of the factors previously identified, including the relatively low status accorded these occupations by society in general.

\section{WOMEN AS MANAGERS IN THE HEALTH SERVICES}

The two professions where women have held managerial positions for more than a century are those of nursing and teaching where an interesting dichotomy exists between two perceptions of these professions. Both are almost exclusively feminine preserves - from the

headmistress or matron to the most junior schoolgirl or nursing student; in the contemporary view - both are supposedly caring, nurturing professions controlled by women who theoretically prefer peopleorientated management styles. Senior managers could be expected to conform to the "feminine" model.

The traditional perception of these two professions however, is of very rigid, hierarchical, militaristic organisations; of a strictly disciplined workforce (or school); of extremely task-orientated, authoritarian, autocratic management styles - far removed from the hypothetical "feminine" model. Headmistresses and matrons were generally regarded as martinets, utilising so called "masculine" management styles.

In attempting to reconcile this conflict a variety of factors should be taken into account.

- The origins of nursing in highly disciplined religious orders and in association with wars and military hospitals.

- Theory $X$ attitudes to management which prevailed until the middle of this century and certainly provided the role models for nursing managers and schoolmistresses until relatively recently.

- Societal norms and values of the Victorian era which persisted into the second half of this century.

- Current societal norms and values which reject totalitarian attitudes, discipline and strict control and encourage questioning minds and participation in decision-making. It can be postulated that the masculine/feminine dichotomy which has been identified in these divergent models results from misconceptions and misleadingly simplistic generalisations, which should not be applied in assessing women's managerial potential or selecting candidates for managerial positions and managerial training. Societal perceptions of feminine and masculine management styles as identified by Bendeman are mythical rather than real. Women's and men's management styles are equally influenced by the standards and behavioural norms of any particular context or era.

Peter said - "Most hierarchies were established by men who now monopolise the upper levels, thus depriving women of their rightful share of opportunities to achieve incompetence". ${ }^{15}$ This is as true in the health services as in any other sphere of human endeavour - but the health services are unique in that women predominate numerically. The proportion of women in managerial positions is, however, low relative to their absolute numerical superiority. This can be partially attributed to the fact that nursing and the professions allied to medicine do not have the same status as medicine and that within medicine itself few women have achieved positions of power.

In order to achieve such positions women have to perform better than their male counterparts by being more able, more innovative, harder working and better educated. In particular women need to become more numerate - to be equally competent in the sciences as in the arts and to escape the mythical feminine (childish) image without losing femininity - rational rather than emotional. Women must also accept responsibility for themselves and to the work situation. High attrition and turnover rates are indicative of an immaturity which prejudices full acceptance of women as equal participants in the work place.

Successful managers, men and women, must be leaders, well qualified and experienced in the theory and practice of management, exhibiting above average 
people skills and an effective structured approach to problem solving and decision making. They must be highly competent with an above-average ability to handle stress and with a vision, purpose and clearly defined personal and organisational goals. At the same time employers must ensure that female employees are able to work responsibly by providing adequate child-care facilities, flexible working hours, shared posts, part-time training opportunities and other support structures - including affirmative action in terms of employment and promotion opportunities for women.

An important step towards changing women's perception of themselves is the integration of the sexes at primary, secondary and tertiary school levels. Single-sex education perpetuates the way women behave by passing on from generation to generation the so-called feminine traits - and excludes women from the powerful "old boy" networks. Training of nursing and paramedical students in isolation from the mainstream of tertiary education inhibits the development of mature personalities, encouraging an "us and them" feminine/masculine dichotomy. Future developments in education must ensure integration of supplementary health-care professional training with general courses at Universities and Technicons, to ensure that future generations of women are not predominantly conditioned by female role models. This integration should also encourage more young men to enter these professions.

At the post-basic level, management training should not be specifically directed at, for example, nursing management. All health-care professionals should attend general multi-disciplinary management courses, where interaction with other professions from the private as well as the public sector would provide the essential holistic view, which is not possible within the limited horizons of a course designed for and attended by a single discipline and gender.

In this country in particular, cross- cultural integration - and research -- is essential. The problems facing white women as the result of years of discrimination are compounded exponentially for other women in southern Africa. This must be addressed not only seeking for solutions but also learning from and adapting to, or adopting, some of the norms and values of other cultures.

\section{CONCLUSION}

Women as managers in the health services must accept responsibility for effecting structural changes in the health care professions and for "networking", providing role models, ensuring their own growth and development - and opening up avenues for other women to follow. Managers are not born they are made. Certain abilities and personality traits may be inherent but development of an individual's managerial potential requires appropriate training - just as gifted singers or artists must be trained in order to achieve their full potential. Women must learn to be effective managers - as people first and women second - utilising appropriate management styles adapted to the environment in which they practice their professional and managerial skills and to the individuals in that environment. ${ }^{16}$ Who know what women can be when they are finally free to become themselves? The health services, because of the predominance of women in the health care professions, offer a unique opportunity for women to achieve this selfactualisation and status and to provide inspiration and create opportunities for all women.

\section{REFERENCES}

1. Freud S. Femininity. In: Strachey J., Freud A., eds. New' Introductory Lectures on Psycho-Analysis and Other Works. Vol. xxii (1932-36). London: The Hogarth Press, 1964: $112-135$
2. Stanhope P.D., 4th Earl of Chesterfield. The Letters of the Earl of Chesterfield to his son: Vol. 1. Strachey C., ed. London: Methuen and Co., 1901: 261-262.

3. Freud. Ibid: 114-116.

4. Kanter R.M. Men and Women of the Corporation. New York: Basic Books, 1977

5. Ames F. Tribulations of a Woman Doctor. MASA News, 1988: 28, 10: 2-6.

6. Oakley A. Wisew'omen and Medicine man: Changes in the Management of Childbirth. In: Mitchell J., Oakley A., eds. The Rights and W'rongs of Women. London: Penguin, 1976: 17-58.

7. Unterhalter B. Discrimination against women in the South African medical profession. Soc Sci Med. 1985, 20 1253-1258.

8. Gamarnikow E. Sexual Division of Labour The Case of Nursing. In: Kahn A., Wolfe A.M., eds. Feminism and Materialism. London: Routledge and Kegan Paul, 1978: 96-123.

9. Unterhalter. ibid.

10. Cilliers G.J. Vroue in Gesondheidsdiensberoepe. In: The Work Situation of South African Women. Pretoria: Human Sciences Research Council, 1987: 149-172.

11. Reskin B.E., Hastanann H.I., eds. Women's Work: Men's Work. Sex Segregation on th Job. Committee on Women's Employment and Related Social Issue. Commission on Behavioural and Social Services and Education. Washington, National Academy Press, 1986.

12. Slabbert I. Bestuursvaardighede. In: The Work Situation of South African Women 173-181.

13. Bendeman H. Die verstand tussen bestuurstyl en die probleme van vroue in bestuur. In: The Work Situation of South African Women: 184-193.

14. Ames. Ibid.

15. Peter L.J. cited in Woman Talk. Brown M., O'Connor A. eds. London: Macdonald and CO., 1985: 135

16. Numerof R E. Practice of Management for Health Care Professionals. New York: American Management Association; 1982 529-553.

J. Kane-Berman, M B. ChB., D.C.H M.Puh. Ad.

Branch: Hospital and Health Services (CPA
In the July issue of CURATIONIS, Volume II Number 2 the acknowledgements to the promoter in the article
"A profile of professional nursing prac-
tice in the private sector in the Republic
of South Africa" was inadvertently left

out. She is Professor W Kotze of the Department of Nursing, University of Port Elizabeth. 